\title{
Some biological data on cactus roach, Rutilus virgo (Heckel), in rivers of the Transcarpathian region of Ukraine
}

\author{
Evgeniy Talabishka, Alexander Didenko, Igor Velykopolskiy
}

Received - 03 March 2015/Accepted - 11 June 2015. Published online: 30 June 2015; @Inland Fisheries Institute in Olsztyn, Poland Citation: Talabishka E., Didenko A., Velykopolskiy I. 2015 - Some biological data on cactus roach, Rutilus virgo (Heckel), in rivers of the Transcarpathian region of Ukraine - Arch. Pol. Fish. 23: 67-77.

\begin{abstract}
The occurrence of Rutilus virgo (Heckel) has been confirmed in the Transcarpathian region of Ukraine, where it was caught in the lower stretches of the Latorica and Borzhava rivers. The comparison of selected morphometric features of $R$. rutilus and $R$. virgo showed that 26 of 40 of them were significantly different and the largest differences were observed for features such as head length, maximum body depth, pectoral fin length, pectoral fin thickness, pelvic fin length, head depth at eye level, maximum head depth, and preorbital length. The comparison of $R$. virgo of two size groups showed a number of changes in fish body proportions during fish growth, where 29 of 38 features were different. Length-weight relationship for mixed sexes was a $=0.0157, b$ $=3.088$. The fecundity of $R$. virgo depended on age and varied from 6775 eggs (age $4+$ ) to 51535 eggs (age 8+). R. virgo inhabiting the rivers of the Transcarpathian region is characterized by relatively rapid growth rate, and the results are within growth rate limits reported in the literature.
\end{abstract}

Keywords: Tisza River, Latorica River, Borzhava River, morphometric features

\footnotetext{
E. Talabishka [ $\left.\Xi^{\circ}\right]$, I. Velykopolskiy

Transcarpathian Research Station for Reproduction of Salmonids and Endangered Fish of the Institute of Fisheries of the National Academy of Agrarian Science of Ukraine Uzhgorodska Str. 165, 89600 Mukachevo, Ukraine e-mail: talabishka@online.ua

A. Didenko

Institute of Fisheries of the National Academy of Agrarian Sciences of Ukraine, Kiev, Ukraine
}

\section{Introduction}

Species of the genus Rutilus (roach) in Ukraine are represented by $R$. rutilus (L.), $R$. frisii (Nordmann), and the introduced R. kutum (Kamensky) (Movchan 2011). However, the latter species is considered to be a subspecies of $R$. frisii (Bogutskaya and Naseka 2004). Cactus roach, Rutilus virgo (Heckel), is not listed in the fish fauna of Ukraine; however, the possibility of its occurrence here is mentioned by Movchan (2011) with a reference to a quite unreliable, non-scientific book (Turyanin 1982). Information on the occurrence of $R$. virgo in the Transcarpathian region of Ukraine is first presented by Turyanin (1982), who probably copied it from Banarescu (1964), and this reference contains detailed data on the distribution of this species in the Tisza river drainage within Romania, and it includes information that it enters some Tisza river tributaries such as the Tur, Borzhava, Batar, and Siren. However, this book does not contain any documented data on actual catches of $R$. virgo, which are crucial for a first description of this species within the territory of Ukraine. Luhovoy and Kovalchuk (1999-2000) indicated its occurrence in lower stretches of the Latorica and Borzhava rivers as well as in the frontier zones of the Tisza River.

The first reliable mention of the occurrence of $R$. virgo in Ukrainian territory was in the paper by 
Harka (2006), in which are indicated sampling sites of this species in the Tisza River upstream from the village of Vilok (Harka 2006). A catch record of one $R$. virgo specimen in the Tisza River near the village of Petrovo in 2010 was erroneously claimed as the first official record in Ukraine (Dolinskiy et al. 2011); however, this is not mentioned in later publications (Dolinskiy et al. 2012a, Dolinskiy et al. 2012b).

Rutilus virgo is recorded in Slovak rivers near the Ukrainian border (Bodrog, Latorica) (Harka 2006, Koščo et al. 2011), in Hungarian stretches of the Tisza River and its tributaries of Tur, Szamos, and Kraszna, in frontier stretches of the Tisza River from Chop to the village of Salovka, and between Tivadar and Lónya (Györe et al. 1995, Harka et al. 1999, Harka 2006, Györe and Józsa 2010). This species also occurs in other countries of the Danube drainage basin, including Austria, Bosnia and Herzegovina, Bulgaria, Croatia, the Czech Republic, Germany, Italy, Macedonia, Montenegro, Romania, Serbia, and Slovenia (Kottelat and Freyhof 2007, Freyhof and Kottelat 2008). There is little information on the biology of this species and literature reports refer mainly to its distribution (Povž et al. 1998). The aim of this study is to increase general knowledge about $R$. virgo inhabiting the territory of the Transcarpathian (Zakarpattya) region of Ukraine, including its biological peculiarities, distribution range, and main differences from $R$. rutilus in external morphology.

\section{Material and methods}

The data were collected in 2009-2012 from different water bodies across the Transcarpathian region of Ukraine (Fig. 1, Table 1). Fish in the Borzhava River were caught using gill nets (length $-35 \mathrm{~m}$, depth $1.8 \mathrm{~m}$, stretch mesh size - 30, 36, 40, 45, $50 \mathrm{~mm}$ ), other fish were caught using angling gears and dip-nets (1 x $1 \mathrm{~m}, 5 \mathrm{~mm}$ mesh). Fish standard length $(S L)$ and weight were measured in the field to the nearest $1 \mathrm{~cm}$ and $0.1 \mathrm{~g}$ using a ruler and electronic scale, respectively. Then the fish caught were preserved in a $4 \%$ formaldehyde solution, and their morphometric features were measured later with an

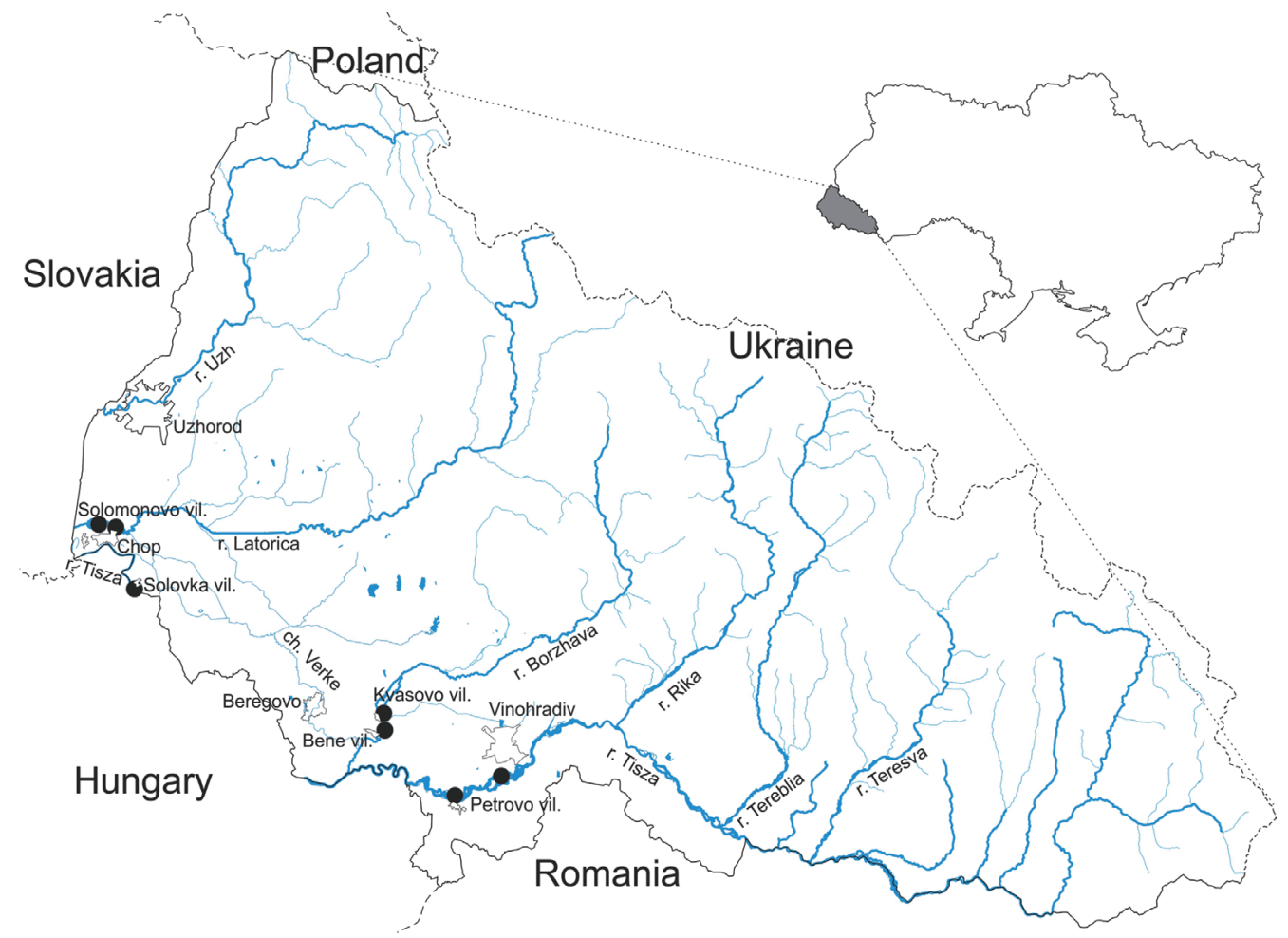

Figure 1. Map of Tisza River drainage in the Tanscarpathian region of Ukraine with locations where R. virgo was found. 
Table 1

Catch location of fish used for biometric analysis

\begin{tabular}{|c|c|c|c|c|}
\hline Species & $\mathrm{n}$ & Place of catchment & Date & Coordinates \\
\hline \multirow{5}{*}{ R. rutilus } & & Stara River (Latorica River tributary) Mukachevo district, & & $48^{\circ} 29^{\prime} 25^{\prime \prime} \mathrm{N}$ \\
\hline & 4 & Znyatsevo village & 16.06.2012 & $22^{\circ} 31^{\prime} 31^{\prime \prime} \mathrm{E}$ \\
\hline & & Slatina canal (Latorica River tributary), Uzhgorod district, & & $48^{\circ} 30^{\prime} 17^{\prime \prime} \mathrm{N}$ \\
\hline & 14 & Velyki Geivtsi village & 9.07 .2012 & $22^{\circ} 21^{\prime} 23^{\prime \prime} \mathrm{E}$ \\
\hline & & & & $48^{\circ} 09^{\prime} 48^{\prime \prime} \mathrm{N}$ \\
\hline \multirow[t]{9}{*}{ R. virgo } & 1 & Borzhava River, Beregovo district, Bene village & $29-30.12 .2011$ & $22^{\circ} 46^{\prime} 44^{\prime \prime} \mathrm{E}$ \\
\hline & & & & $48^{\circ} 09^{\prime} 48^{\prime \prime} \mathrm{N}$ \\
\hline & 15 & Borzhava River, Beregovo district, Bene village & 25.11.2011 & $22^{\circ} 46^{\prime} 44^{\prime \prime} \mathrm{E}$ \\
\hline & & & & $48^{\circ} 11^{\prime} 33^{\prime \prime} \mathrm{N}$ \\
\hline & 2 & Borzhava River, Beregovo district, Kvasovo village & 20.10 .2011 & $22^{\circ} 46^{\prime} 24^{\prime \prime} \mathrm{E}$ \\
\hline & & & & $48^{\circ} 27^{\prime} 24^{\prime \prime} \mathrm{N}$ \\
\hline & 1 & Latorica River, Uzhgorod district, Solomonovo village & $12-13.06 .2011$ & $22^{\circ} 10^{\prime} 18^{\prime \prime} \mathrm{E}$ \\
\hline & & & & $48^{\circ} 27^{\prime} 3^{\prime \prime} \mathrm{N}$ \\
\hline & 14 & Latorica River, Uzhgorod district, near Ukrainian-Slovak border & $21-22.07 .2012$ & $22^{\circ} 10^{\prime} 10^{\prime \prime} \mathrm{E}$ \\
\hline
\end{tabular}

electronic caliper to the nearest $0.1 \mathrm{~mm}$. Fish sex was determined by abdominal cavity dissection. Female gonads were removed and weighed with electronic scales to the nearest $0.01 \mathrm{~g}$. Absolute fecundity was determined by the gravimetric method (Bagenal and Braum 1978). Relative fecundity was found as the ratio of total number of eggs to total weight of fish. Age was determined using scales. A part of the collected material (7 specimens ) was deposited in the archival collection of the National Museum of Natural History of the National Academy of Sciences of Ukraine.

Measurements and calculations of 40 morphometric and 13 meristic characters were performed. The following abbreviations were used in the tables and text: Features included morphometric measurements: $S L$ - standard body length (the measurement from the anterior-most tip of the body to the midlateral posterior edge of the hypural plate); $\%$ relatively $S L$ : $T L$ - total length; $l c$ - head length; $H$ maximum body depth, $h$ - minimum body depth; $i H$ - maximum body width; ih - body length at minimum body depth; $a D$ - predorsal length; $p o D$ postdorsal length; $p P$ - prepectoral length; $p V$ prepelvic length; $p A$ - preanal length; $P A$ - distance between the pectoral and anal fin bases; $P V$ - distance between pectoral and pelvic fin bases; $V A$ - distance between pelvic and anal fin bases; lpc length of caudal peduncle; $l C_{1}$ - length of caudal fin upper lobe; $l C_{3}$ - length of lower lobe of caudal fin; $h p c$ - depth of caudal peduncle; lapc - width of caudal peduncle; $l D$ - length of base of dorsal fin; $h D$ dorsal fin maximum depth; $h D f$ - dorsal fin minimum depth; $l A$ - length of base of anal fin; $h A$ - depth of anal fin; $l P$ - length of pectoral fin; lpbs - length of pectoral fin base; th.P - thickness of pectoral fin (Talabishka 2010); $l V$ - length of pelvic fin; $l V b s$ length of base of pelvic fin; $V$-an - distance from the beginning of the pelvic fin base to the anal orifice; an- $A$ - distance from the anal orifice to the anal fin base; \% of head length: ho1 - head depth at eye level; $h c$ - maximum head depth; lr - preorbital length (snout length); $O$ - horizontal eye diameter; $p o O$ postorbital length; lac - head width; io - interorbital length; $\operatorname{lm} x$ - upper jaw length; ina - distance between the nostrils; and meristic characters: l.l. - total number of scales in the lateral line; l.l. with pores number of scales in the lateral line with pores; l.l. without pores - number of scales in the lateral line without pores; $\mathrm{Du}$ - number of unbranched rays in the dorsal fin; $D b$ - number of branched rays in the dorsal fin; $A u$ - number of unbranched rays in the anal fin; $A b$ - number of branched rays in the anal 
fin; $P$ - number of rays in the pectoral fin; $V$-number of rays in the pelvic fin; $C$ - number of rays in the caudal fin; $S q u_{1}$ - number of transverse scales between the lateral line and the origin of the dorsal fin; Squ $u_{2}$ number of transverse scales between the lateral line and the origin of the anal fin; cir - number of circumpendicular scales. All features except $S L$ were expressed in percent of $S L$ or in percent of $l c$.

The length-weight relationship was calculated using the equation (Le Cren 1951):

$$
W=a \times S L^{b}
$$

where $\mathrm{W}$ is the total weight in $\mathrm{g}, S L$ is the standard length in $\mathrm{cm}$, $\mathrm{a}$ is the intercept, and $b$ is the slope of the regression.

The Fulton condition factor was estimated using the equation (Anderson and Neumann 1996):

$$
K=\left(W \times S L^{-3}\right) \times 100,000
$$

The morphometric measurements and meristic characters of $R$. virgo and $R$. rutilus and morphometric measurements of two size groups of $R$. virgo were compared using the $t$-test. The $t$-test was applied to \% values. Calculations were performed in MS Excel 2010, while statistical analysis was performed in Statistica 8.0.

\section{Results and discussion}

The results confirm that two Rutilus species inhabit the Transcarpathian region of Ukraine. Rutilus rutilus is quite common and widespread (Movchan and Smirnov 1981), while $R$. virgo seems to have a narrower range (Fig. 1). Local people, mainly the Hungarian minority, clearly identify cactus roach in the frontier zones of the Tisza River and the lower stretches of the Borzhava River as "leánykoncér" (this name is also mentioned by Luhovoy and Kovalchuk (1999-2000)), which is the Hungarian name for this fish, while other people usually confuse this species with ide, Leuciscus idus (L.). In the Ukrainian part of the Latorica River, $R$. virgo is sometimes called "Danube roach," but mostly the two Rutilus species are not distinguished and are referred to as "plitka" or "plotva" or "plotica" (the name for roach in Ukrainian, Russian, and Slovak, respectively). It is noteworthy that the name "plotica" is often used by local people in the Transcarpathian region for spirlin, Alburnoides bipunctatus (Bloch), and this confuses some recreational fishers.

The comparison of the morphometric features of $R$. rutilus and $R$. virgo showed that 26 of 40 of them were significantly different (Table 2). The greatest differences were observed in features such as head length $(l c)$, maximum body depth $(H)$, length of pectoral fin $(l P)$, thickness of pectoral fin $(t h . P)$, length of pelvic fin $(l V)$, head depth at eye level (ho), maximum head depth $(h c)$, and preorbital length $(l r)$. The total length (TL) of $R$. rutilus is somewhat greater, which is related to the longer length of the lower lobe of the caudal fin that allows differentiating this species from $R$. virgo in the field; however, since the caudal peduncle is quite susceptible to mechanical damage, this feature differentiation should used in consideration of this fact. Maximum body depth $(H)$, caudal peduncle base depth $(h)$, maximum body width $(i H)$, and width of caudal peduncle (lapc) of $R$. virgo are smaller than those of $R$. rutilus.

The pectoral fins in $R$. virgo are located somewhat closer to the head, while the pelvic fins are a little bit farther away from it in comparison to $R$. rutilus. This location of the pelvic fins influences the pectoventral $(P V)$ and ventroanal $(V A)$ lengths and the distance from the pelvic fin to the anal orifice. The location of the anal fin in both species is exactly the same as is reflected in the preanal $(p A)$ and pectoanal $(P A)$ lengths and the caudal peduncle length, for which no significant differences were detected. $R$. rutilus is characterized by a higher and wider caudal peduncle ( $h p c$ and lapc), has a relatively larger length of base of dorsal fin $(l D)$ and posterior edge depth $(h D f)$ compared to $R$. virgo; however, the maximum depths of the dorsal fins $(h D)$ of both species are exactly the same. The anal fin $(h A)$ in $R$. virgo is smaller, but the lengths of its base $(l A)$ in the two species are similar. The pectoral and pelvic fins in $R$. rutilus are relatively larger in all features except the length ofpectoral fin base (lpbs), which are exactly the same in both species. These two species are distinctly different in features that 
Table 2

Comparison of morphometric measurements of $R$. virgo and $R$. rutilus from the Transcarpathian region of Ukraine

\begin{tabular}{|c|c|c|c|c|c|c|}
\hline \multirow[b]{2}{*}{ Features } & \multicolumn{2}{|c|}{$R . \operatorname{virgo}(\mathrm{n}=14)$} & \multicolumn{2}{|c|}{ R. rutilus $(\mathrm{n}=15)$} & \multirow[b]{2}{*}{$\mathrm{t}$} & \multirow[b]{2}{*}{$\mathrm{P}$} \\
\hline & mean $\pm \mathrm{SE}$ & $\min -\max$ & mean $\pm \mathrm{SE}$ & $\min -\max$ & & \\
\hline SL & $83.1 \pm 4.29$ & $68.5-118.6$ & $83.4 \pm 2.7$ & $65.2-102.4$ & 0.05 & 0.957 \\
\hline \multicolumn{7}{|l|}{$\% \mathrm{SL}$} \\
\hline$T L$ & $126.1 \pm 0.79$ & $118.8-130.3$ & $128.3 \pm 0.48$ & $125.9-131.7$ & 2.52 & 0.018 \\
\hline$l c$ & $25.4 \pm 0.25$ & $23.5-27.0$ & $26.9 \pm 0.22$ & $25.4-28.1$ & 4.49 & $<0.001$ \\
\hline$H$ & $26.2 \pm 0.35$ & $23.9-28.8$ & $30.2 \pm 0.38$ & $26.5-32.1$ & 7.66 & $<0.001$ \\
\hline$h$ & $9.8 \pm 0.1$ & $9.1-10.2$ & $10.4 \pm 0.12$ & $9.3-11.1$ & 3.77 & 0.001 \\
\hline$i H$ & $12.9 \pm 0.18$ & $11.5-13.7$ & $13.9 \pm 0.19$ & $12.5-15.1$ & 3.50 & 0.002 \\
\hline$i h$ & $3.9 \pm 0.13$ & $3.1-5.0$ & $5 \pm 0.28$ & $3.5-6.7$ & 3.27 & 0.003 \\
\hline$a D$ & $53.6 \pm 0.31$ & $50.3-55.1$ & $54.2 \pm 0.4$ & $51.6-56.5$ & 1.04 & 0.309 \\
\hline$p o D$ & $34.9 \pm 0.24$ & $33.6-36.8$ & $34.7 \pm 0.48$ & $32.3-38.6$ & 0.42 & 0.679 \\
\hline$p P$ & $25.9 \pm 0.22$ & $24.2-27.0$ & $26.7 \pm 0.25$ & $24.8-28.7$ & 2.45 & 0.021 \\
\hline$p V$ & $53.1 \pm 0.31$ & $50.3-55.0$ & $52 \pm 0.35$ & $50.1-54.6$ & 2.26 & 0.032 \\
\hline$p A$ & $73.6 \pm 0.33$ & $70.9-75.2$ & $74.1 \pm 0.54$ & 69.9-77.7 & 0.77 & 0.447 \\
\hline$P A$ & $49.1 \pm 0.35$ & $46.5-50.6$ & $48.9 \pm 0.67$ & $43.6-52.8$ & 0.27 & 0.790 \\
\hline$P V$ & $27.7 \pm 0.36$ & $25.1-29.9$ & $25.6 \pm 0.41$ & $22.1-28.1$ & 3.84 & 0.001 \\
\hline$V A$ & $22.1 \pm 0.29$ & $19.9-24.2$ & $23.9 \pm 0.5$ & $19.1-26.4$ & 3.12 & 0.004 \\
\hline$l p c$ & $17.5 \pm 0.25$ & $15.3-19.2$ & $17.6 \pm 0.36$ & $14.1-19.6$ & 0.26 & 0.794 \\
\hline$l C_{1}$ & $27.4 \pm 0.36$ & $24.8-30.3$ & $27.9 \pm 0.44$ & 25.6-32.3 & 0.72 & 0.477 \\
\hline$l C_{3}$ & $27.8 \pm 0.3$ & $25.8-29.7$ & $29.1 \pm 0.39$ & $27.1-31.6$ & 2.52 & 0.019 \\
\hline$h p c$ & $28.2 \pm 0.54$ & 24.6-31.1 & $30.2 \pm 0.53$ & $28.3-34.8$ & 2.72 & 0.012 \\
\hline lapc & $0.6 \pm 0.02$ & $0.4-0.7$ & $0.7 \pm 0.02$ & $0.6-0.8$ & 3.44 & 0.002 \\
\hline$l D$ & $14.4 \pm 0.16$ & $13.1-15.5$ & $15.3 \pm 0.23$ & $13.8-17.3$ & 3.12 & 0.004 \\
\hline$h D$ & $23.3 \pm 0.19$ & $22.1-24.6$ & $23.9 \pm 0.57$ & $17.2-26.1$ & 0.98 & 0.334 \\
\hline$h D f$ & $9.0 \pm 0.16$ & 7.7-9.9 & $9.7 \pm 0.21$ & $8.2-11.3$ & 2.43 & 0.022 \\
\hline$l A$ & $12.3 \pm 0.12$ & $11.6-13.1$ & $12.6 \pm 0.23$ & $10.8-14.3$ & 1.03 & 0.314 \\
\hline$h A$ & $15.9 \pm 0.22$ & $14.5-17.1$ & $16.9 \pm 0.31$ & 15.4-19.9 & 2.47 & 0.020 \\
\hline$l P$ & $17.3 \pm 0.14$ & $16.2-18.1$ & $19.1 \pm 0.3$ & $17.2-21.5$ & 5.45 & $<0.001$ \\
\hline lpbs & $3.6 \pm 0.08$ & $3.0-4.0$ & $3.6 \pm 0.11$ & $3.0-4.6$ & 0.19 & 0.854 \\
\hline th. $P$ & $0.6 \pm 0.02$ & $0.6-0.7$ & $0.8 \pm 0.04$ & $0.6-1.1$ & 4.11 & $<0.001$ \\
\hline$l V$ & $17.2 \pm 0.16$ & $16.0-18.0$ & $18.3 \pm 0.2$ & $17-19.5$ & 4.39 & $<0.001$ \\
\hline$l V b s$ & $3.7 \pm 0.11$ & $3.2-4.7$ & $4.1 \pm 0.1$ & $3.5-5.1$ & 2.69 & 0.012 \\
\hline$V$-an & $20.4 \pm 0.29$ & $18.7-22.1$ & $22.6 \pm 0.51$ & $18.8-26.4$ & 3.64 & 0.001 \\
\hline an- $A$ & $1.9 \pm 0.13$ & $1.1-3.1$ & $1.5 \pm 0.13$ & $0.8-2.3$ & 1.95 & 0.062 \\
\hline \multicolumn{7}{|l|}{$\%$ lc } \\
\hline ho1 & $54.1 \pm 0.4$ & $52.5-57.0$ & $57.5 \pm 0.44$ & $52.9-60$ & 5.59 & $<0.001$ \\
\hline$h c$ & $68.7 \pm 0.74$ & 64-73.1 & $73.6 \pm 0.59$ & $68.2-76.4$ & 5.20 & $<0.001$ \\
\hline$l r$ & $28.3 \pm 0.36$ & $25.7-30.7$ & $26 \pm 0.28$ & $23.8-27.6$ & 5.07 & $<0.001$ \\
\hline$O$ & $26.4 \pm 0.4$ & $24.2-29.5$ & $26.5 \pm 0.43$ & $24.1-30.6$ & 0.14 & 0.886 \\
\hline poO & $46.6 \pm 0.73$ & $41.4-50.2$ & $48.7 \pm 0.38$ & $45.9-51.2$ & 2.58 & 0.016 \\
\hline lac & $48.4 \pm 0.51$ & $45.0-51.6$ & $49.5 \pm 0.49$ & $46.4-52.7$ & 1.62 & 0.117 \\
\hline io & $34.9 \pm 1.17$ & 20.9-39.0 & $36.2 \pm 0.36$ & $34.1-39.0$ & 1.12 & 0.272 \\
\hline $\operatorname{lm} x$ & $24.4 \pm 0.43$ & $21.4-26.9$ & $22.8 \pm 0.34$ & $20.5-25.0$ & 2.91 & 0.007 \\
\hline ina & $19.9 \pm 0.47$ & $17.0-23.4$ & $20.2 \pm 0.42$ & $17.9-24.4$ & 0.42 & 0.675 \\
\hline
\end{tabular}

characterize the head in the head depth at eye level (ho) and maximum head depth $(h c)$; these features are significantly larger in $R$. rutilus. Most significantly, $R$. virgo differs in its larger snout length $(l r)$ and to a somewhat lesser degree in upper jaw length $(\operatorname{lm} x) . R$. rutilus also differs somewhat from $R$. virgo in its larger post-orbital distance $(p o O)$, while all remaining features are similar.

Unlike the measurements presented by Misik (1957) who compared two Rutilus species of different size groups (157.39 $\pm 2.17 \mathrm{~mm}$ for $R$. rutilus and $287.25 \pm 6.20 \mathrm{~mm}$ for $R$. virgo), the fish used in the 
Evgeniy Talabishka et al.

Table 3

Comparison of morphometric measurements of two size groups of $R$. virgo from the Transcarpathian region of Ukraine

\begin{tabular}{|c|c|c|c|c|c|c|}
\hline \multirow[b]{2}{*}{ Features } & \multicolumn{2}{|l|}{ Small $(n=19)$} & \multicolumn{2}{|l|}{ Large $(n=13)$} & \multirow[b]{2}{*}{$\mathrm{t}$} & \multirow[b]{2}{*}{$\mathrm{P}$} \\
\hline & mean $\pm \mathrm{SE}$ & $\min -\max$ & mean $\pm \mathrm{SE}$ & $\min -\max$ & & \\
\hline SL & $105.1 \pm 9.39$ & $68.5-182.1$ & $286.4 \pm 11.7$ & $225.1-346.3$ & 12.15 & $<0.001$ \\
\hline \multicolumn{7}{|l|}{$\% \mathrm{SL}$} \\
\hline$T L$ & $104.6 \pm 0.94$ & 97.5-119.9 & $104.8 \pm 0.19$ & 103.8-106.0 & 0.15 & 0.885 \\
\hline$l c$ & $24.5 \pm 0.40$ & $21.6-27.0$ & $20.5 \pm 0.23$ & $19.1-21.8$ & 7.68 & $<0.001$ \\
\hline$H$ & $27.1 \pm 0.44$ & $23.9-31.4$ & $30.9 \pm 0.67$ & $26.2-34.7$ & 5.04 & $<0.001$ \\
\hline$h$ & $9.9 \pm 0.09$ & $9.1-10.6$ & $10.1 \pm 0.12$ & $9.1-10.7$ & 1.60 & 0.121 \\
\hline$i H$ & $13.0 \pm 0.18$ & $11.5-14.6$ & $13.8 \pm 0.14$ & $12.7-14.4$ & 2.95 & 0.006 \\
\hline$i h$ & $4.3 \pm 0.17$ & $3.1-5.9$ & $5.2 \pm 0.13$ & $4.5-6.2$ & 4.27 & $<0.001$ \\
\hline$a D$ & $53.4 \pm 0.45$ & $47.5-57.3$ & $53.6 \pm 0.42$ & $50.8-56.1$ & 0.28 & 0.780 \\
\hline$p o D$ & $36.0 \pm 0.55$ & $33.6-43.3$ & $39.8 \pm 0.52$ & $37.2-42.8$ & 4.80 & $<0.001$ \\
\hline$p P$ & $25.4 \pm 0.29$ & $22.4-27.0$ & $22.6 \pm 0.26$ & $21.1-24.4$ & 6.78 & $<0.001$ \\
\hline$p V$ & $53.1 \pm 0.3$ & $50.3-55.7$ & $54.4 \pm 0.49$ & $51.3-57.1$ & 2.39 & 0.023 \\
\hline$p A$ & $74.2 \pm 0.41$ & 70.9-78.8 & $77.8 \pm 0.64$ & $74.0-81.2$ & 4.97 & $<0.001$ \\
\hline$P A$ & $50.4 \pm 0.62$ & $46.5-56.9$ & $55.3 \pm 0.67$ & $52.3-59.5$ & 5.26 & $<0.001$ \\
\hline$P V$ & $28.6 \pm 0.47$ & $25.1-33.0$ & $33.0 \pm 0.36$ & $31.0-35.3$ & 6.89 & $<0.001$ \\
\hline$V A$ & $22.7 \pm 0.37$ & $19.9-26.6$ & $24.2 \pm 0.41$ & $21.7-26.6$ & 2.63 & 0.013 \\
\hline$l p c$ & $18.4 \pm 0.43$ & $15.3-22.5$ & $20.0 \pm 0.3$ & $17.5-21.6$ & 2.74 & 0.010 \\
\hline$l C_{1}$ & $26.3 \pm 0.52$ & $22.5-30.3$ & $22.7 \pm 0.38$ & $20.2-24.9$ & 5.17 & $<0.001$ \\
\hline$l C_{3}$ & $26.8 \pm 0.49$ & $23.4-29.7$ & $22.6 \pm 0.39$ & $19.9-24.9$ & 6.23 & $<0.001$ \\
\hline$h p c$ & $30.9 \pm 1.28$ & $24.6-43.0$ & $41.4 \pm 0.75$ & $37.2-46.1$ & 6.41 & $<0.001$ \\
\hline lapc & $0.6 \pm 0.02$ & $0.4-0.7$ & $0.6 \pm 0.02$ & $0.4-0.8$ & 0.79 & 0.437 \\
\hline$l D$ & $14.6 \pm 0.15$ & $13.1-16.2$ & $14.8 \pm 0.18$ & $13.7-15.8$ & 0.88 & 0.388 \\
\hline$h D$ & $23.1 \pm 0.22$ & $20.1-24.6$ & $22.0 \pm 0.3$ & $20.4-23.9$ & 3.01 & 0.005 \\
\hline$h D f$ & $8.9 \pm 0.14$ & 7.7-9.9 & $8.9 \pm 0.16$ & $7.8-10.1$ & 0.02 & 0.981 \\
\hline$l A$ & $12.2 \pm 0.14$ & 11.1-13.1 & $12.4 \pm 0.17$ & $11.5-13.4$ & 1.28 & 0.210 \\
\hline$h A$ & $15.4 \pm 0.26$ & $13.2-17.1$ & $13.6 \pm 0.16$ & $12.2-14.3$ & 5.28 & $<0.001$ \\
\hline$l P$ & $17.1 \pm 0.16$ & $15.1-18.1$ & $16.5 \pm 0.14$ & $15.5-17.7$ & 3.07 & 0.005 \\
\hline lpbs & $3.8 \pm 0.09$ & $3-4.6$ & $4.5 \pm 0.06$ & $4.0-4.9$ & 5.51 & $<0.001$ \\
\hline th. $P$ & $0.6 \pm 0.01$ & $0.6-0.7$ & $0.7 \pm 0.02$ & 0.6-0.9 & 4.60 & $<0.001$ \\
\hline$l V$ & $17.3 \pm 0.17$ & $16-18.8$ & $16.3 \pm 0.2$ & $15.2-17.6$ & 3.91 & 0.001 \\
\hline$l V b s$ & $3.9 \pm 0.11$ & $3.2-4.8$ & $5.1 \pm 0.1$ & $4.4-5.5$ & 7.34 & $<0.001$ \\
\hline \multicolumn{7}{|l|}{$\%$ lc } \\
\hline ho1 & $52.7 \pm 0.77$ & $44.0-57.0$ & $50.6 \pm 1.18$ & $44.2-58.5$ & 1.49 & 0.146 \\
\hline$h c$ & $70.0 \pm 0.79$ & $64.0-77.4$ & $76.6 \pm 1.23$ & $70.6-85.3$ & 4.75 & $<0.001$ \\
\hline$l r$ & $27.5 \pm 0.44$ & 23.3-30.7 & $28.8 \pm 0.41$ & $26.8-31$ & 2.22 & 0.034 \\
\hline$O$ & $26.0 \pm 0.38$ & $22.6-29.5$ & $20.9 \pm 0.35$ & $18.8-23$ & 9.38 & $<0.001$ \\
\hline poO & $46.7 \pm 0.56$ & $41.4-50.2$ & $48.7 \pm 0.31$ & $47.3-50.7$ & 2.75 & 0.010 \\
\hline lac & $49.7 \pm 0.68$ & $45.0-56.1$ & $53.7 \pm 0.55$ & $49.8-56.9$ & 4.25 & $<0.001$ \\
\hline io & $36.4 \pm 0.46$ & 32.9-39.6 & $39.0 \pm 0.56$ & $36.2-42.6$ & 3.53 & 0.001 \\
\hline $\operatorname{lm} x$ & $23.9 \pm 0.45$ & $20.6-26.9$ & $22.9 \pm 0.45$ & $20.1-25.2$ & 1.72 & 0.095 \\
\hline
\end{tabular}

present work were of nearly the same size, which permitted for more distinct highlighting of the features that differ in these two similar species. Compared to Misik's (1957) data, the present results of morphometric measurements do not indicate such noticeable differences between $R$. rutilus and $R$. virgo. However, it is noteworthy that both comparisons of this pair demonstrated similar tendencies in features such as head depth and length ( $l c$ and $h c$ ), body depth $(H)$, body length $(T L)$, and pectoral fin length $(l P)$. Some features, including preanal length, anal fin depth, eye diameter, and others, were more varied in different size groups of the same species (e.g., R. virgo Table 3) than they were in the two Rutilus species. These two species differ most in meristic characters in the number of scales in the 
Table 4

Comparison of meristic characters of $R$. virgo and $R$. rutilus from the Transcarpathian region of Ukraine

\begin{tabular}{|c|c|c|c|c|c|c|c|c|}
\hline \multirow[b]{2}{*}{ Features } & \multicolumn{3}{|c|}{$R$. virgo } & \multicolumn{3}{|c|}{ R. rutilus } & \multirow[b]{2}{*}{$\mathrm{t}$} & \multirow[b]{2}{*}{$\mathrm{P}$} \\
\hline & $\mathrm{n}$ & mean $\pm \mathrm{SE}$ & $\min -\max$ & $\mathrm{n}$ & mean $\pm \mathrm{SE}$ & $\min -\max$ & & \\
\hline l.l. & 32 & $46.8 \pm 0.18$ & $45-49$ & 18 & $42.1 \pm 0.21$ & $41-43$ & 16.4 & $<0.001$ \\
\hline l.l. with pores & 32 & $45.6 \pm 0.15$ & $44-47$ & 18 & $40.7 \pm 0.18$ & $40-42$ & 19.84 & $<0.001$ \\
\hline l.l. without pores & 32 & $1.3 \pm 0.12$ & $0-3$ & 18 & $1.4 \pm 0.14$ & $1-3$ & 0.73 & 0.472 \\
\hline$D u$ & 32 & $3 \pm 0.03$ & $2-3$ & 18 & 3 & & 0.75 & 0.459 \\
\hline$D b$ & 32 & $10.7 \pm 0.07$ & $10.5-11.5$ & 18 & $10.3 \pm 0.1$ & $9.5-10.5$ & 3.19 & 0.002 \\
\hline$A u$ & 32 & $2.9 \pm 0.04$ & $2-3$ & 18 & 3 & & 1.07 & 0.288 \\
\hline$A b$ & 32 & $11.6 \pm 0.12$ & $10.5-13.5$ & 18 & $10.4 \pm 0.08$ & $9.5-10.5$ & 6.98 & $<0.001$ \\
\hline$P$ & 20 & I $16.6 \pm 0.18$ & I 14-I 18 & 18 & I $15.4 \pm 0.27$ & I 13-I 17 & 3.43 & 0.002 \\
\hline$V$ & 20 & I $8.1 \pm 0.05$ & I 8-I 9 & 18 & I $7.9 \pm 0.06$ & I 7-I 8 & 1.42 & 0.165 \\
\hline C & 20 & $18.8 \pm 0.14$ & $17-19$ & 18 & $18.9 \pm 0.08$ & $18-19$ & 0.55 & 0.587 \\
\hline$S q u_{1}$ & 32 & $7.8 \pm 0.08$ & $7-8$ & 18 & $8.1 \pm 0.08$ & $8-9$ & 3.04 & 0.004 \\
\hline $\mathrm{Squ}_{2}$ & 32 & $4.5 \pm 0.1$ & $4-6$ & 18 & 4 & & 3.96 & $<0.001$ \\
\hline $\operatorname{cir}$ & 31 & $14 \pm 0.07$ & $13-15$ & 18 & $13.9 \pm 0.13$ & $13-15$ & 0.43 & 0.669 \\
\hline
\end{tabular}

lateral line, the values of which were higher in $R$. virgo (Table 4). The differences in the number of scales with pores in the lateral line were much larger, while the number of scales without pores was almost the same in both species. These fishes also differed in the number of scales under and above the lateral line. No differences between the two species were noted in the number of unbranched rays in all the fins. As for branched rays, the largest difference was observed in the branched rays of the anal fin $(A b)$ and to a somewhat lesser degree for those in the dorsal fin $(D b)$. A difference was also observed in the number of branched rays in the pectoral fin $(P)$. The number of branched rays in the pelvic and caudal fins were similar in both species. Overall, the results in the present study of the comparison of meristic characters are fully consistent with those obtained by Misik (1957), who also found significant differences between the two Rutilus species in the number of scales in the lateral line (l.l.) and the number of branched rays in the anal $(A b)$ and pectoral $(P)$ fins.

The comparison of two samples of $R$. virgo from different size groups showed that a number of changes occur in body proportions during growth (Table 3). The features of 19 fish with an average length of 105.1 mm were compared to those of 13 fish with an average length of $286.4 \mathrm{~mm}$. Relative changes in virtually all examined morphometric features was noted. Features such as maximum body depth $(H)$, maximum body width $(i H)$, and depth of caudal peduncle $(h p c)$ increased; however, the minimum body depth $(h)$ remained unchanged. The most significant reduction in length was noted in the head during ontogenesis. Fish growth caused increases in relative features, which was reflected in fin locations ( $p o D, p V, p A, P A, P V$, $V A, l p c)$, but, predorsal length $(a D)$ remained unchanged, while prepectoral length $(p P)$ even decreased, which was probably linked with the relative reduction in head length. The upper and lower caudal peduncle lobes $\left(l C_{1}\right.$ and $\left.l C_{3}\right)$ reduce in length with growth, while the relative caudal peduncle depth increased $(h p c)$ at its unchanged width (lapc). The maximum dorsal fin length $(h D)$ decreased, but the length $(I D)$ and depth of its posterior edge ( $h D f)$ remained unchanged. The measurements of the anal fin changed similarly. The length of the pectoral and pelvic fins ( $I P$ and $l V$ ) reduced as the fish grew in parallel with increased base length. The relative thickness of the pectoral fins also increased. Changes in head measurements were observed in all features examined 
Table 5

Fecundity parameters of $R$. virgo from the Transcarpathian region of Ukraine (November 2011)

\begin{tabular}{lllllll}
\hline \hline No & $\begin{array}{l}\text { Age } \\
\text { (years) }\end{array}$ & $\begin{array}{l}\text { Standard } \\
\text { length }(\mathrm{mm})\end{array}$ & $\begin{array}{l}\text { Body weight } \\
(\mathrm{g})\end{array}$ & Gonad weight $(\mathrm{g})$ & $\begin{array}{l}\text { Absolute fecundity } \\
(\mathrm{eggs})\end{array}$ & $\begin{array}{l}\text { Relative fecundity } \\
\left(\mathrm{eggs}^{-1}\right)\end{array}$ \\
\hline \hline 1 & $4+$ & 225.1 & 237 & 15.28 & 6775 & 28.6 \\
2 & $4+$ & 253.0 & 312 & 23.80 & 10543 & 33.8 \\
3 & $6+$ & 285.0 & 505 & 48.50 & 20370 & 40.3 \\
4 & $6+$ & 300.0 & 606 & 60.32 & 26907 & 44.4 \\
5 & $6+$ & 300.0 & 624 & 61.70 & 27333 & 43.8 \\
6 & $7+$ & 344.7 & 893 & 83.27 & 39986 & 49.5 \\
7 & $8+$ & 346.3 & 912 & 105.70 & 45153 & 57.8 \\
8 & $8+$ & 331.5 & 891 & 116.07 & 51535 & 42.9 \\
Mean & & 298.2 & 622.5 & 64.33 & 28575 & \\
\hline \hline
\end{tabular}

except in head depth above eye level (ho1) and length of upper jaw $(\operatorname{lm} x)$. Relative head depth and width $(h c$ and lac) increased with interorbital length (io). Snout length (lr) and postorbital length $(p o O)$ increased with head length growth because of the reduction in eye diameter $(O)$ relative to head length.The relative increase in certain features as the fish grew, such as snout length $(l r)$ or postorbital length ( $p o O)$, occurs in cyprinids as an adaptation related to changes in biotope (i.e., the move from the littoral to the profundal zone) and predation on larger benthic organisms (Zhiteneva 2002). Similar increases of various features and other body proportions were also noted in $R$. virgo: $i H$, ih, poD, $p A, P A, V A, l p c, h p c$, lpbs, th.P, lVbs, hc, lac, io. The relative lengths of other features $(h, a D, h D f, l A, h o 1, \operatorname{lm} x)$ did not change with fish growth, and the rest of the relative lengths of parameters decreased during fish ontogenesis.

The comparison of the current data with those in the literature (Misik 1957), namely fish of an average size of $286.4 \mathrm{~mm}$ collected in Ukraine (Table 3) and fish of an average size of $287.25 \mathrm{~mm}$ collected in Slovakia, indicated high similarity. Features such as interorbital length $(i O)$, horizontal eye diameter $(O)$, length of head $(l c)$, maximum body depth $(H)$, and body width $(i H)$, length of caudal peduncle $(l p c)$, minimum body depth $(h)$, length of anal fin base $(l A)$ and anal fin depth $(h A)$, and distance between the bases of the pelvic and anal fins $(V A)$ were all nearly the same. Other features varied slightly: the lengths of the pectoral $(l P)$ and ventral $(l V)$ fins and the maximum depth of the dorsal fin $(h D)$ were larger in fish collected in the Transcarpathian region, while postorbital distance $(p O)$ and length of caudal peduncle $(l C)$ were larger in fish collected in the Danube, the Little Danube, and the Hron (Misik 1957). These differences can be attributed to the fact that they were measured by different researchers. However, a few features were significantly different: the pectroventral $(P V)$, preventral $(p V)$, and preanal $(p A)$ distances were larger in fish from Ukraine, while length of snout (lr) and head width (lac) were smaller. The largest difference was maximum head depth $(h c)$, which was only $76.6 \%$ of $l c$ in fish from the Transcarpathian region, while in the fish collected by Misik (1957) it was $87.2 \%$ of $l c$.

The length-weight relationship for mixed sexes of $R$. virgo was: $\mathrm{a}=0.0157, b=3.088(\mathrm{~min} S L=3.2 \mathrm{~cm}$, $\max S L=34.6 \mathrm{~cm} ; \min \mathrm{W}=0.58 \mathrm{~g}, \max \mathrm{W}=912.0 \mathrm{~g}$; $\left.n=31 ; r^{2}=0.9988\right)$. The fecundity of $R$. virgo caught in the Borzhava River depended on age and ranges from 6775 to 51535 eggs (Table 5); this is quite consistent with data reported in the literature for cactus roach at 25000-30000 eggs (Holčík 1995). However, $R$. virgo fecundity was much lower compared to that of $R$. rutilus. For example, the absolute fecundity of roach $(S L \geq 30 \mathrm{~cm})$ inhabiting the Dnieper River reservoirs usually exceeds 100000 eggs (Movchan and Smirnov 1981). Of the 13 fish caught in the Borzhava River, 8 were females and 5 were males. 
Table 6

Growth parameters of $R$. virgo from the Transcarpathian region of Ukraine

\begin{tabular}{lllllll}
\hline \hline & & \multicolumn{2}{l}{ Standard length $(\mathrm{cm})$} & \multicolumn{2}{l}{ Body weight $(\mathrm{g})$} \\
\cline { 3 - 6 } Age & $\mathrm{n}$ & mean & min-max & mean & min-max & Fulton condition factor \\
\hline \hline $1+$ & 4 & 7.08 & $6.85-7.19$ & 6.6 & $5.3-7.4$ & 1.86 \\
$2+$ & 9 & 8.47 & $7.40-11.86$ & 12.3 & $7.8-28.3$ & 2.03 \\
$3+$ & 3 & 15.18 & $11.86-17.17$ & 74.4 & $33.2-107.0$ & 2.13 \\
$4+$ & 4 & 20.36 & $17.51-23.20$ & 178.3 & $109.0-246.0$ & 2.11 \\
$5+$ & 2 & 25.06 & $24.35-25.76$ & 306.5 & $257.0-356.0$ & 1.95 \\
$6+$ & 5 & 28.36 & $28.0-30.0$ & 498.8 & $312.0-624.0$ & 2.19 \\
$7+$ & 1 & 34.7 & 34.7 & 893.0 & 893.0 & 2.18 \\
$8+$ & 2 & 33.89 & $33.2-34.6$ & 901.5 & $891.0-912.0$ & 2.32 \\
\hline \hline
\end{tabular}

Table 7

Habitat characteristics of $R$. virgo catch locations

\begin{tabular}{|c|c|c|c|}
\hline River & Borzhava & Latorica & Latorica \\
\hline Placement & village of Bene & village of Solomonovo & \\
\hline Coordinates & $\begin{array}{l}48^{\circ} 09^{\prime} 48^{\prime \prime} \mathrm{N} \\
22^{\circ} 46^{\prime} 44^{\prime \prime} \mathrm{E}\end{array}$ & $\begin{array}{l}48^{\circ} 27^{\prime} 3^{\prime \prime} \mathrm{N} \\
22^{\circ} 10^{\prime} 10^{\prime \prime} \mathrm{E}\end{array}$ & $\begin{array}{l}48^{\circ} 27^{\prime} 24^{\prime \prime} \mathrm{N} \\
22^{\circ} 10^{\prime} 18^{\prime \prime} \mathrm{E}\end{array}$ \\
\hline Width of the river $(\mathrm{m})$ & 30 & 16 & $15-33$ \\
\hline Depth of the river $(\mathrm{m})$ & $2.5-4$ & $1-2$ & $1-3$ \\
\hline Velocity $\left(\mathrm{m} \mathrm{s}^{-1}\right)$ & 0.1 & 0.1 & 0.1 \\
\hline Bottom surface & snagged, silted & $\begin{array}{l}\text { sandy-clayey with isolated } \\
\text { silted areas }\end{array}$ & snagged, clayey \\
\hline Aquatic vegetation & $\begin{array}{l}\text { submerged aquatic vegetation } \\
\text { (Potamogeton sp.) }\end{array}$ & $\mathrm{n} / \mathrm{a}$ & $\mathrm{n} / \mathrm{a}$ \\
\hline Banks & steep and covered with trees and bushes & densely covered with trees & densely covered with trees \\
\hline Channel structure & $\begin{array}{l}\text { snagged by trees falling into the water } \\
\text { from clearing banks of vegetation }\end{array}$ & $\begin{array}{l}\text { the river channel greatly } \\
\text { meanders in this reach } \\
\text { forming multiple oxbows, } R \text {. } \\
\text { virgo was found only in } \\
\text { mainstream }\end{array}$ & $\begin{array}{l}\text { the river channel greatly } \\
\text { meanders in this reach } \\
\text { forming multiple oxbows, } \\
R \text {. virgo was found only in } \\
\text { mainstream }\end{array}$ \\
\hline Syntopic species & $\begin{array}{l}\text { Squalius cephalus, I. idus, Chondrostoma } \\
\text { nasus, Alburnus alburnus, Blicca } \\
\text { bjoerkna, Abramis brama, Ballerus sapa, } \\
\text { Aspius aspius, Barbus barbus, Cobitis } \\
\text { elongatoides, Silurus glanis, Esox lucius } \\
\text { Sander lucioperca }\end{array}$ & $\begin{array}{l}\text { S. cephalus, } R \text {. rutilus, } A \text {. } \\
\text { bipunctatus, A. alburnus, B. } \\
\text { bjoerkna, Romanogobio } \\
\text { vladykovi, S. glanis, E. } \\
\text { lucius, Lepomis gibbosus, } \\
\text { Perca fluviatilis, } \\
\text { Gymnocephalus baloni }\end{array}$ & $\begin{array}{l}\text { A. bipunctatus, } \\
\text { G. baloni, } P . \text { fluviatilis, } R \text {. } \\
\text { vladykovi, } R \text {. rutilus }\end{array}$ \\
\hline Remarks & $\begin{array}{l}\text { there is a dam located } 5 \mathrm{~km} \text { downstream } \\
\text { (build in 1892) by which the water level } \\
\text { in the sampling sites in spring raises by } \\
\text { approx. } 1 \mathrm{~m}\end{array}$ & $\begin{array}{l}\text { great amounts of snags and } \\
\text { litter of human origin (plastic } \\
\text { bottles, bags, etc.) in the river } \\
\text { channel }\end{array}$ & $\begin{array}{l}\text { great amounts of snags } \\
\text { and litter of human origin } \\
\text { (plastic bottles, bags, etc.) } \\
\text { in the river channel }\end{array}$ \\
\hline
\end{tabular}


$R$. virgo inhabiting rivers of the Transcarpathian region was characterized by a relatively rapid growth rate (Table 6), and the present results were within the growth rate limits reported in the literature (Holčík 1995). However, the mean age values of fish older than $5+$ are somewhat higher. It is necessary to note that the fish studied were caught in different seasons (mid-summer and late autumn), and the samples were relatively small, and this probably resulted in some inconsistency, e.g., differences between age 1+ and $2+$ fish were very small, while $7+$ fish were a little bit longer than fish aged $8+$. Because the fish in the Bozrhava River were caught at the end of November, individuals aged $3+$ to $8+$ can be considered to be fish aged from $4+$ to $9+$. The growth rate of $R$. virgo seemed to be higher than that of $R$. rutilus in Ukrainian water bodies, e.g., roach aged $5+$ and $6+$ rarely exceeds $20 \mathrm{~cm}$ in Ukrainian rivers and reservoirs (Movchan and Smirnov 1981). Habitat characteristics are presented in Table $7 . R$. virgo juveniles (aged $0+, 1+, 2+$ ) were observed in shallow waters of the Latorica River channel at night (20:00-03:00) in summer (July). They fed actively and reacted to electric light, but they remained on site, while larger individuals escaped to the depths. During winter, fish caught using gill nets (older age groups) did not feed; however, some individuals aged $1+$ to $4+$ were caught with angling gears, and this indicates feeding activity in this species during this period.

In conclusion, $R$. virgo can be officially listed in the fauna of Ukraine for the Transcarpathian region (Zakarpatska oblast) in rivers that belong to the Tisza River drainage basin. Additional studies are necessary to identify in more detail the distribution range and biological characteristics of this rare species in this location.

Author contributions. E.T. performed statistical analysis, analyzed data, and wrote the draft of the manuscript, A.D. supervised the research and wrote the final version of the manuscript, I.V. contributed to the draft of the manuscript. All authors participated in designing the research, fish sampling, and morphometric measurements.

\section{References}

Anderson R.O., Neumann R.M. 1996 - Length, weight, and associated structural indices - In: Fisheries techniques (Eds) B.R. Murphy, D.W. Willis, American Fisheries Society. Bethesda: 447-482.

Bagenal T.B., Braum E. 1978 - Eggs and early life history - In: Methods for assessment of fish production in fresh waters, $3^{\text {rd }}$ edition (Ed.) T.M. Bagenal, IBP Handbook No 3, Blackwell Scientific Publications, Oxford: 165-201.

Bănărescu P. 1964 - Pisces - osteichthyes. Fauna Republicii Populare Romine, 13th editura - Academiei Republicii Populare Romine, Bucuresti, 962 p. (in Romanian).

Bogutskaya N.G., Naseka A.M. 2004 - Catalog of agnathans and fishes of fresh and brackish waters of Russia with comments on nomenclature and taxonomy - KMK Scientific Press Ltd. Moscow, 389 p. (in Russian).

Dolinskiy V.L., Afanasyev S.A., Savchenko E.V., Abramyuk I.I. 2011 - Pannonian roach Rutilus virgo (Heckel, 1852) (Pisces, Cyprinidae). New species of the ichthyofauna of Ukraine - In: Proc. IV Inter. Ichthyological scientific-practical conference. Modern problems of theoretical and practical ichthyology, 7-11 September 2011, Odessa: 86-89 (in Russian).

Dolinskiy V.L., Afanasyev S.A., Savchenko E.V., Abramyuk I.I. 2012a - Reports of cactus roach (Pisces, Cyprinidae) in waters of Ukraine - Vest. zool. 46: 18 (in Russian).

Dolinskiy V., Afanasyev S., Savchenko E., Abramyuk I., Velykopolskiy I. 2012b - Finding of Rutilus virgo (Heckel, 1852) (Pisces, Cyprinidae) in the Ukrainian section of the Upper Tisa basin - Proc. 39th IAD Conference Living Danube 21-24 August 2012, Szentendre, Hungary: 95.

Freyhof J., Kottelat M. 2008 - Rutilus virgo - In: The IUCN Red List of Threatened Species. Version 2015.1. <www.iucnredlist.org>. Accessed February 1, 2013.

Györe K., Józsa V. 2010 - Monitoring of the fish community of River Tisza in 2009 - Pisces Hungarici 4: 39-59 (in Hungarian with English summary).

Györe K., Sallai Z., Csikai Cs. 1995 - Fish Fauna of the Upper Tisza in Hungary - Halászat 85: 144-148 (in Hungarian with English summary).

Harka Á. 2006 - Changes in the fish fauna of the River Tisza Tiscia. 35: 65-72.

Harka Á., Bănărescu P.M., Telcean I. 1999 - Fish Fauna of the Upper Tisza - In: The Upper Tisza Valley (Eds) J. Hamar, A. Sárkány-Kiss, Szeged: 439-454.

Holčík J. 1995 - Rutilus pigus (Lacépède, 1804) - In: Fauna ČR a SR, Mihulovci Petromyzontes a ryby Osteichthyes (2) (Eds) V. Baruš, O. Oliva, Academia, Praha: 24-28 (in Czech). 
Koščo J., Pekárik L., Košuthová L., Nowak M. 2011 Ichthyofauna of the Slovak part of River Bodrog - Pisces Hungarici 5: 117-122.

Kottelat M., Freyhof J. 2007 - Handbook of European Freshwater Fishes - Kottelat, Cornol, Switzerland and Freyhof, Berlin, Germany, 646 p.

Le Cren E.D. 1951 - The length-weight relationship and seasonal cycle in gonad weight and condition in the perch (Perca fluviatilis). - J. Aquat. Ecol. 20: 201-219.

Luhovoy O., Kovalchuk A. 1999-2000 - Rare fauna of Zakarpattia - „Lira“, Uzhgorod 122 p. (in Ukrainian).

Misik V. 1957 - Biometrika plotice lesklej Dunajskej Rutilus pigus (Lacépède 1804) virgo (Heckel 1852) - Biologia, Bratislava. 12: 177-191 (in Slovak).

Movchan Yu.V., Smirnov A.I. 1981 - Fauna of Ukraine. Fishes. Cyprinid Fishes. Part 1 - Naukova Dumka Publishing House, Kyiv, 423 p. (in Ukrainian).

Movchan Yu.V. 2011 - Fishes of Ukraine - Zoloti Vorota Publishing House, 444 p. (in Ukrainian).
Povž M., Šumer S., Leiner S. 1998 - Sport fishing catch as an indicator of population size of the Danube roach Rutilus pigus virgo in Slovenia (Cyprinidae) - Ital. J. Zool. 65 (Supll. 1): 545-548.

Talabishka E.M. 2010 - Sexual dimorphism of Gobio carpathicus Vladykov, 1925 from Prut and Tisza rivers Reports of young researchers-zoologists Conference, Kyiv: 52 (in Ukrainian).

Turyanin I.I. 1982 - Fishes of Carpathian waters - Karpaty, Uzhgorod, 144 p. (in Ukrainian).

Zhiteneva T.S. 2002 - Regularities of Changes in Body Proportions of Bream (Abramis brama L., Cyprinidae) at Stages and Transitions of the Late Ontogenesis Hydrobiol. J. 38: 40-49 (in Russian). 